\title{
Stability and Storage Studies on Banana pulp by Ohmic Heating and Conventional Heating
}

\author{
P. Poojitha and K.A. Athmaselvi ${ }^{1}$ \\ Department of Food Process Engineering, School of Bioengineering, SRM University, \\ Kattankulathur, Chennai-603203, Tamilnadu, India. \\ http://dx.doi.org/10.13005/bbra/2157
}

(Received: 02 April 2016; accepted: 03 May 2016)

\begin{abstract}
The demand for fresh foods with longer shelf life is increasing day by day. The conventional pasteurization reduces the microbial count but easily affects the organoleptic properties. In order to enhance the shelflife and quality of the product ohmic heating technique is used. Ohmic heating is a fast heating method for food products. This is a food processing technique in which the liquid or semi-solid foods are sterilized without any physical damage as caused in conventional heating. In ohmic heating processes, foods are made part of an electric circuit through which alternating current flows, causing heat to be generated within the foods due to the electrical resistance of the foods. In this study, banana pulp without sugar and with different concentrations of sugar is ohmically heated and the changes in physiochemical properties are compared with that of conventional heating. The electrical conductivity, $\mathrm{pH}$, total soluble solids, acidity before and after heat treatment were also analysed. Meanwhile, the pulp was stored in refrigeration temperature without adding preservatives and the shelf life of the ohmic heated and conventional heated banana pulp was also studied. Consequently, it is been found that ohmic heated pulp has maximum shelf life than conventionally heated pulp.
\end{abstract}

Keywords: Ohmic heating, Conventional heating, Banana pulp, Physiochemical properties and shelf life.

\begin{abstract}
Conventional way of heating fundamentally involves the heat transfer mechanism of conduction, convection and radiation. It leads to heterogenous treatment and knownloss of product quality ${ }^{1}$. In order to inhibit these problems, substitutive technologies using electrical energy directly in the food processing have dragged interest in the food industry ${ }^{2-5}$.

Ohmic heating is an electro-thermal technique of processing. It is a food processing technique in which the alternating current (AC) passes through the food and leads to inner
\end{abstract}

\footnotetext{
* To whom all correspondence should be addressed.
}

generation of energy in foods ${ }^{6}$. During Ohmic heating, a mild electroporation happens forming holes in the cell membrane leading to allowance of ions through the pores to the electrode with opposite charges leading to generation of heat. Ohmic heating is grounded on the transit of electrical current (AC) through a body such as a liquid particulate food system which acts as an electrical resistance in which heat is generated. The most important elements of ohmic heating are electrical conductivity and its temperature dependence. The electrical conductivity increases with rising temperature, hinting that ohmic heating becomes more effective as temperature increases ${ }^{7,8}$.

The banana, one of the most ate up foods in the world, is from the Musa genus. Bananas can be categorized into two groups, namely plantain and dessert bananas. The qualities of the fresh banana decrease drastically after harvesting as a 
consequence of impairment in fruit's colour, flavour and texture. In order to increase its shelf life and reduce the loss, ripe bananas can be treated into various products such as banana pulp, banana juice, beverages, jam and jelly $[9,10,11]$. Banana fruit is basically rich in minerals such as potassium, magnesium and phosphorus, dietary fibre, and various antioxidants such as vitamin A,vitamin C, vitamin $\mathrm{E}$, and $\beta$ carotene ${ }^{[12]}$.

\section{MATERIALSAND METHODS}

\section{Sample preparation}

Cavendish bananas were procured from local market, Gudvancherry, India. The samples were washed, peeled, cut with sterilized knife and pulped. The banana pulp is divided into four equal parts. The first part is maintained without sugar, to the second, third and fourth shares $10 \%, 30 \%$ and $50 \%$ sugar is added. Once the sample is prepared, the main parameters including $\mathrm{pH}$, TSS, colour, acidity, ascorbic acid content and reducing sugar are determined.

\section{Experimental equipment and procedure}

The ohmic heating system consists of rheostat, voltmeter, ammeter, power supply and titanium electrodes. The area of the ohmic heating cell was found to be $134.4 \mathrm{~cm}^{2}$. The distance between the two electrodes is $6 \mathrm{~cm}$. A Teflon coated thermometer is used to measure the temperature at different locations in the cell.

The banana pulp of specified amount was sandwiched between two electrodes in the test cell. The sample was ohmically heated at three different voltage gradients 13.33, 20 and $26.66 \mathrm{~V} /$ $\mathrm{cm}$. Ohmic heating is done till the pulp start to bubble and it is kept for 2 minutes to enhance the shelf life. The temperature and ammeter values are noted simultaneously.

\section{Electrical conductivity}

Electrical conductivity (ó) was determined from the resistance of the sample and the geometry of the cell using the following equation: $\sigma=\mathrm{LI} / \mathrm{AV}$

where ó is the electrical conductivity ( $\mathrm{S}$ / $\mathrm{m}) \mathrm{L}$ is the gap between two electrodes (m); $\mathrm{A}$ is the area of the cell; I is the current (A); and V is the voltage (V).
After ohmic heating of pulp without sugar and with 10\%, 30\% and 50\% sugar, the physical and biochemical properties are again measured.

\section{pH measurement}

The $\mathrm{pH}$ of the banana pulp before and after heat treatment is measured using digital $\mathrm{ph}$ meter which is initially calibrated with $\mathrm{pH}$ buffer $7^{13}$.

\section{Total Soluble Solids}

Total Soluble Solids in the juice were determined with a hand refractometer, calibrated using distilled water ${ }^{13}$.

\section{Acidity}

Total titratable acidity (TA) was measured according to the method described (Ranganna, 2001). The pulp is filtered and titrated against $0.1 \mathrm{~N}$ $\mathrm{NaOH}$. Total acid\% is calculated in terms of malic acid in the pulp ${ }^{14}$.

$$
\text { Acidity } \%=\frac{\begin{array}{c}
\text { Titre value } \mathrm{x} \text { Normality of alkali } \mathrm{x} \text { volume made up } \\
\mathrm{x} \text { equivalent weight of acid }
\end{array}}{\begin{array}{c}
\text { volume of sample taken for estimation } \mathrm{x} \\
\text { weight of sample taken } \mathrm{x} 1000
\end{array}} \times 100
$$

\section{Colour}

The $\mathrm{L}$, $\mathrm{a}$ and $\mathrm{b}$ values were measured using Hunter colourimeter. Total color difference was calculated using:

$\mathrm{TCD}=\sqrt{(\mathrm{Lo}-\mathrm{L})^{2}+(a o-a)^{2}}+(b o-b)^{2}$

\section{Ascorbic acid}

The ascorbic acid content in the pulp before and after processing is determined by titrating the filtered sample against the dye solution of sodium bicarbonate and dichlorophenol indophenols.

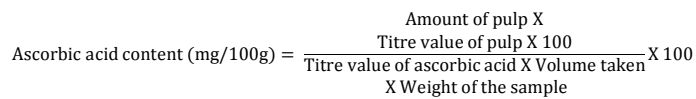

\section{Microbial study}

The number of colonies was determined in the pulp, by plating in nutrient agar media. The number of colonies was calculated using a colony counter. The study was carried out at an interval of 15 days .

$$
\frac{\mathrm{CFU}}{\mathrm{ml}}=\frac{\begin{array}{c}
\text { Number of colonies X } \\
\text { reciprocal of dilution factor }
\end{array}}{\text { Volume of sample }}
$$


sample was heated further in order to maintain the shelf life the conductivity started to decrease as shown in fig. 2. Similar results were also reported ${ }^{[18]}$ for lemon juice and ${ }^{[17]}$ for orange juice. Many studies have shown that the electrical conductivity increases with the increase in temperature for different fruit samples ${ }^{[19]}$. The value of electrical conductivity obtained is similar to that of the peach puree as reported ${ }^{[17]}$. The electrical conductivity depends on concentration and temperature, for lemon juice ${ }^{[15]}$.

\section{Effect of parameters on ohmic heating of pulp with different sugar concentration Effect of pH, Total soluble solids and Acidity}

In the light of experimental results shown in Table 1, there was a slight change in the $\mathrm{pH}$ of the banana pulp based on the applied voltage gradient and sugar concentration. The range of the banana pulp $\mathrm{pH}$ after ohmic treatments was 4.5 -4.63. The initial $\mathrm{pH}$ of the banana pulp was found

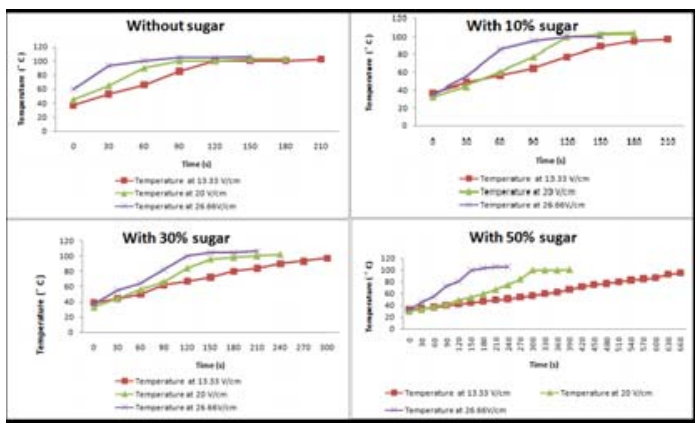

Fig.1. Time-Temperature profile of Ohmic heated banana pulp

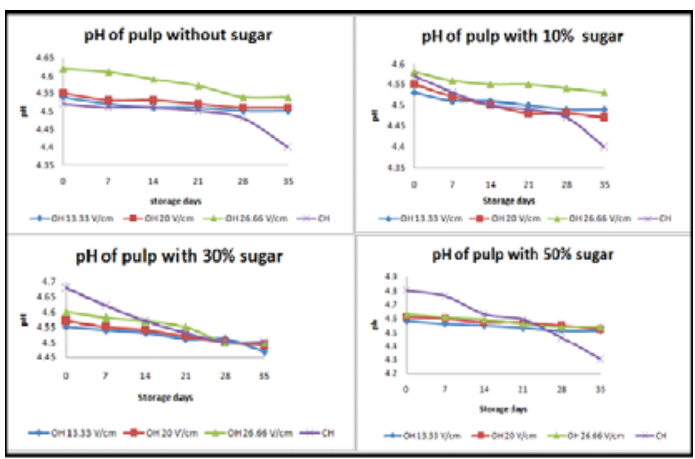

Fig. 3a. Representation of change in $\mathrm{pH}$ of pulp during storage to be 4.5 and it was constant even after the addition of different concentration of sugar. With increase in voltage gradient, the $\mathrm{pH}$ of the pulp with various sugar concentrations also increased ${ }^{[19]}$. The change in $\mathrm{pH}$ regulates the change in \% acidity. Initially, when the pulp with $10 \%, 30 \%$ and $50 \%$ sugar concentration and without sugar was treated at $13.33 \mathrm{~V} / \mathrm{cm}$, the $\%$ acidity was found to be $0.75 \%$, $0.66 \%, 0.65 \%$ and $0.61 \%$ respectively. On further treatment with increasing voltage gradient, the $\%$ acidity decreased gradually. The decrease in malic acid can be due to the conversion of organic acids into sugars. ${ }^{[20]}$ suggested that at high temperature, the acidity tends to decrease in certain orange cultivars. As the organic acids are converted into sugars or utilized for energy synthesis, the titratable acidity decreases. When pulp with 50\% sugar was treated at high voltage gradient, the \% acidity decreased upto $0.45 \%$. The amount of dissolved sugar and soluble solids present in a

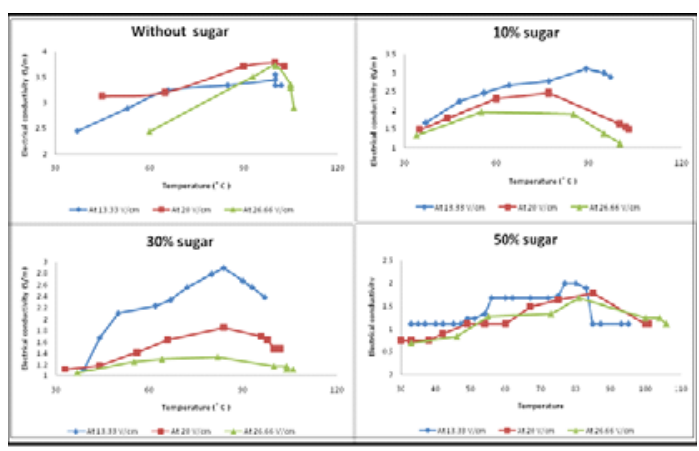

Fig. 2. Electrical conductivity of Ohmic heated pulp

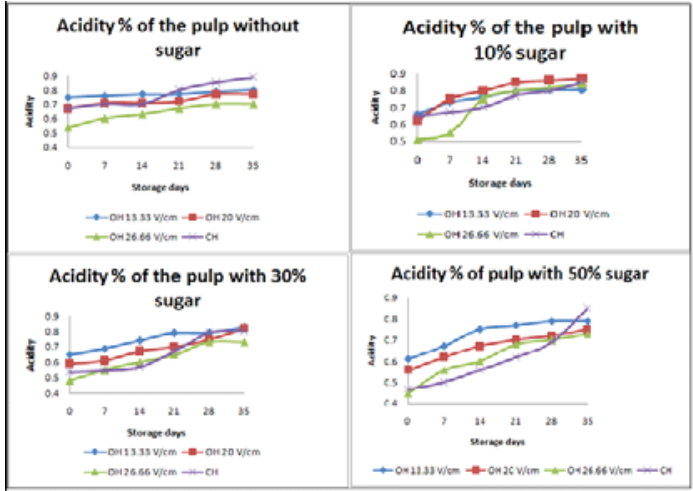

Fig. 3b. Representation of change in acidity of pulp during storage 


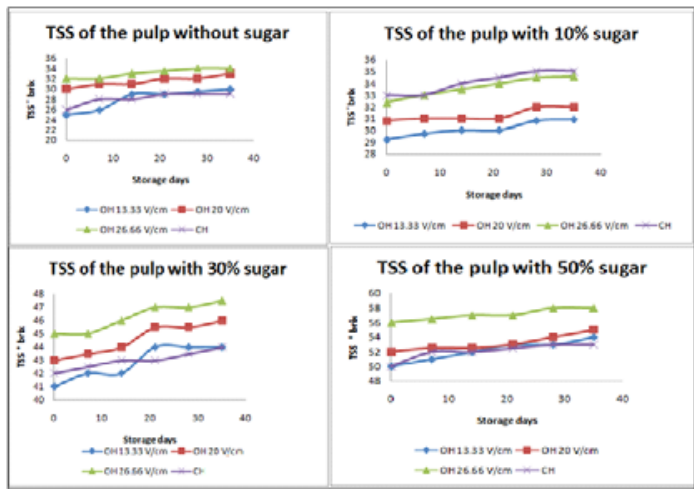

Fig. 4. Representation of change in TSS of pulp during storage

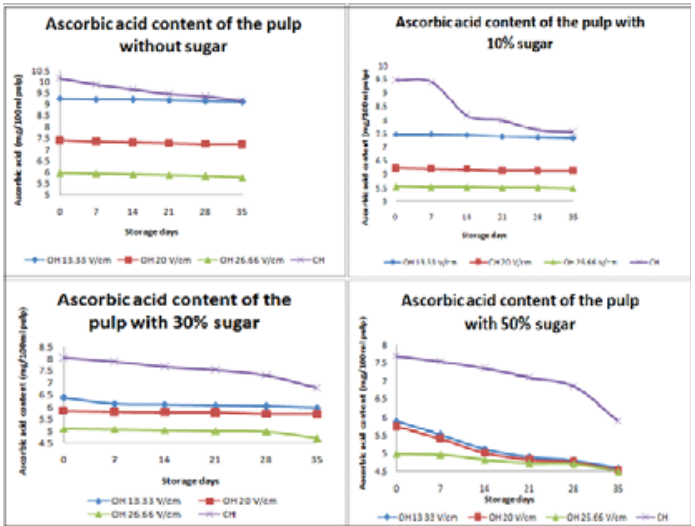

Fig. 6. Representation of change in ascorbic acid content of pulp during storage

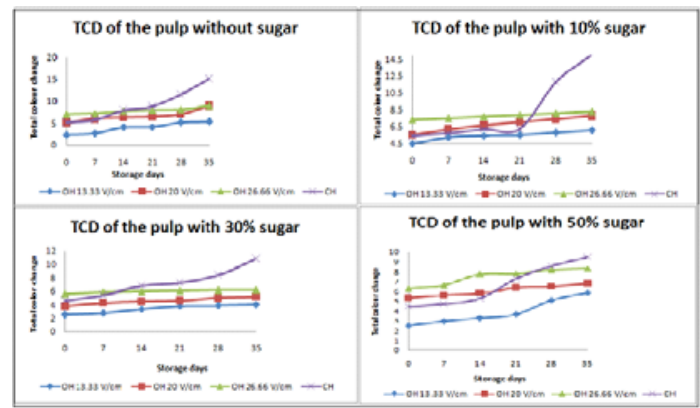

Fig. 5. Representation of change in colour of pulp during storage

\section{RESULTSAND DISCUSSION}

\section{Analysis of banana pulp before ohmic heating}

The different physiochemical properties of banana pulp were analysed and given in Table 1 .

Effect of temperature and voltage gradient on rate of Ohmic heating

The heating rate was higher at higher voltages. Bubblings were observed at $85 \mathrm{C}$, when the pulp with different sugar concentrations was heated at higher voltage gradients. The heating

Table 1. pH, Acidity and Total soluble solid of banana pulp with different sugar concentration at various voltage gradient.

\begin{tabular}{|c|c|c|c|c|}
\hline Voltage gradient V/cm & $\begin{array}{l}\text { Fresh pulp } \\
\text { without sugar }\end{array}$ & $\begin{array}{c}\text { Fresh pulp } \\
\text { with } 10 \% \text { sugar }\end{array}$ & $\begin{array}{c}\text { Fresh pulp } \\
\text { with 30\% sugar }\end{array}$ & $\begin{array}{c}\text { Fresh pulp } \\
\text { with 50\% sugar }\end{array}$ \\
\hline \multicolumn{5}{|l|}{$\mathrm{pH}$} \\
\hline Before $\mathrm{OH}$ & 4.5 & 4.5 & 4.5 & 4.5 \\
\hline 13.33 & 4.54 & 4.53 & 4.55 & 4.58 \\
\hline 20 & 4.55 & 4.55 & 4.57 & 4.61 \\
\hline 26.66 & 4.62 & 4.58 & 4.6 & 4.63 \\
\hline Conventional heating & 4.52 & 4.57 & 4.68 & 4.8 \\
\hline \multicolumn{5}{|l|}{ Acidity \% } \\
\hline Before $\mathrm{OH}$ & 0.8 & 0.8 & 0.804 & 0.807 \\
\hline 13.33 & 0.75 & 0.66 & 0.65 & 0.61 \\
\hline 20 & 0.67 & 0.62 & 0.59 & 0.56 \\
\hline 26.66 & 0.54 & 0.51 & 0.48 & 0.45 \\
\hline Conventional heating & 0.67 & 0.65 & 0.536 & 0.469 \\
\hline \multicolumn{5}{|c|}{ Total Soluble Solids R” brix } \\
\hline Before $\mathrm{OH}$ & 22 & 27 & 40 & 46 \\
\hline 13.33 & 25 & 29.2 & 41 & 50 \\
\hline 20 & 30 & 30.8 & 43 & 52 \\
\hline 26.66 & 32 & 32.4 & 45 & 56 \\
\hline Conventional heating & 26 & 33 & 42 & 47 \\
\hline
\end{tabular}


time increased with increase in sugar concentration as shown in fig.1. The rise in temperature was also dependent on the sugar concentration. At $13.33 \mathrm{~V} /$ $\mathrm{cm}$, the time required to heat the pulp without sugar and with $10 \%, 30 \%$ and $50 \%$ sugar was observed to be 90 s, 120s, 240s and 540s.Similar observation was done at $20 \mathrm{~V} / \mathrm{cm}$ and $26.66 \mathrm{~V} / \mathrm{cm}$. A bubbling temperature of $74 \mathrm{C}$ was reached within $45 \mathrm{~s}$ when lemon juice was ohmically heated at $30-55 \mathrm{~V} / \mathrm{cm}^{[15]}$. The ohmic heating of tomato juice at $50-70 \mathrm{~V} / \mathrm{cm}$ 48 s to reach a temperature of $80 \mathrm{C}^{[16]}$. The heating rate decreased with increase in voltage gradient.
Ohmic heating of tomato paste, at $6 \mathrm{~V} / \mathrm{cm}$, showed that the time taken to reach $96 \mathrm{C}$ was 235s; whereas at $14 \mathrm{~V} / \mathrm{cm}$ the time taken to reach the same temperature was 38s ${ }^{[15]}$. A bubbling temperature of upto $90 \mathrm{C}$ was reached when grape juice was ohmic heated at 20 to $40 \mathrm{~V} / \mathrm{cm}^{[17]}$.

\section{Electrical conductivity}

For the banana pulp with different sugar concentrations, the electrical conductivity increased linearly till the bubbling temperature. This increase is due to the increase in the ionic mobility and solute concentration. When the

Table 2. Change in color of the ohmic heated pulp of different sugar concentration at various voltage gradients

\begin{tabular}{|c|c|c|c|c|c|c|c|c|c|c|c|c|}
\hline \multirow{2}{*}{$\begin{array}{l}\text { Voltage gradie } \\
\text { V/cm } \\
\text { Before } \mathrm{OH}\end{array}$} & \multicolumn{3}{|c|}{$\begin{array}{l}\text { Fresh pulp } \\
\text { without sugar }\end{array}$} & \multicolumn{3}{|c|}{$\begin{array}{c}\text { Fresh pulp } \\
\text { with } 10 \% \text { sugar }\end{array}$} & \multicolumn{3}{|c|}{$\begin{array}{c}\text { Fresh pulp } \\
\text { with 30\% sugar }\end{array}$} & \multicolumn{3}{|c|}{$\begin{array}{c}\text { Fresh pulp } \\
\text { with 50\% sugar }\end{array}$} \\
\hline & L & $\mathrm{a}$ & b & $\mathrm{L}$ & $\mathrm{a}$ & b & $\mathrm{L}$ & a & b & $\mathrm{L}$ & $\mathrm{a}$ & B \\
\hline & 59.18 & 6.63 & 17.68 & 55.7 & 6.67 & 18.7 & 54.75 & 6.72 & 19.73 & 54.06 & 7.54 & 20.71 \\
\hline 13.33 & 58.75 & 6.59 & 16.58 & 51.74 & 6.65 & 17.5 & 53.7 & 6.67 & 17.91 & 52 & 7.27 & 18.56 \\
\hline 20 & 55.23 & 5.85 & 15.23 & 50.94 & 6.47 & 16.5 & 53.55 & 6.65 & 17.47 & 49.51 & 7.11 & 18.41 \\
\hline 26.66 & 53.61 & 4.79 & 15 & 49.25 & 5.42 & 16.1 & 50.64 & 6.41 & 16.86 & 48.61 & 7.06 & 17.14 \\
\hline
\end{tabular}

Table 3. Change in ascorbic acid content of the ohmic heated pulp of different sugar concentration at various voltage gradients

\begin{tabular}{lcccc}
\hline $\begin{array}{l}\text { Voltage } \\
\text { gradient V/cm }\end{array}$ & $\begin{array}{c}\text { Fresh pulp } \\
\text { without sugar }\end{array}$ & $\begin{array}{c}\text { Fresh pulp } \\
\text { with 10\% Sugar } \\
\text { [mg/100ml pulp] }\end{array}$ & $\begin{array}{c}\text { Fresh pulp } \\
\text { with 30\% sugar }\end{array}$ & $\begin{array}{c}\text { Fresh pulp } \\
\text { with 50\% sugar }\end{array}$ \\
\hline Before OH & 11.11 & 8.45 & 7.59 & 7.11 \\
13.33 & 9.25 & 7.48 & 6.38 & 5.9 \\
20 & 7.4 & 6.2 & 5.84 & 5.73 \\
26.66 & 5.95 & 5.55 & 5.11 & 4.98 \\
\hline
\end{tabular}

Table 4. Number of colonies observed in ohmic heated and conventionally heated pulp

\begin{tabular}{|c|c|c|c|c|c|}
\hline $\begin{array}{l}\text { Storage } \\
\text { days }\end{array}$ & Treatment & $\begin{array}{c}\text { Ohmic } \\
\text { heating } 80 \mathrm{~V}\end{array}$ & $\begin{array}{c}\text { Ohmic } \\
\text { heating } 120 \mathrm{~V} \\
\text { CFU/ml }\end{array}$ & $\begin{array}{c}\text { Ohmic } \\
\text { heating } 160 \mathrm{~V}\end{array}$ & $\begin{array}{c}\text { Conventional } \\
\text { heating }\end{array}$ \\
\hline 15 & Without sugar & No & No & No & 8 \\
\hline 30 & & 2 & 2 & 1 & 17 \\
\hline 15 & $10 \%$ sugar & 10 & 8 & 4 & 16 \\
\hline 30 & & 27 & 15 & 7 & 31 \\
\hline 15 & $30 \%$ sugar & 6 & 4 & 2 & 14 \\
\hline 30 & & 10 & 13 & No & 27 \\
\hline 15 & $50 \%$ sugar & No & No & No & 12 \\
\hline 30 & & 1 & 1 & No & 20 \\
\hline
\end{tabular}


food product can be termed as total soluble solids. It is an essential parameter for fruit based products. The TSS of the ohmic heated pulp of different sugar concentrations varied from 22 R"brix to 56 R"brix at various voltage gradients. This increase is due to loss of water due to heating. As proposed by ${ }^{[21]}$, this increase can also be due to conversion of organic acids to sugars. The maximum value was obtained when the pulp was treated at $26.66 \mathrm{~V} / \mathrm{cm}$. Change in colour

The voltage gradient has a substantial effect on color. The $\mathrm{L}$ value was observed to decrease with increase in voltage gradient. The decrease in colour is linked with browning of pulp ${ }^{[22]}$. Browning occurs due to the presence of oxygen and metal ions. Oxidative enzymes in the fruits influence the discolouration of fruit pulp ${ }^{[7]}$. The Table 2 shows the colour change of pulp without sugar and with $10 \%, 30 \%$ and $50 \%$ sugar treated at different voltage gradients.

\section{Change in ascorbic acid}

As in Table 3, the voltage gradient and sucrose concentration have effect on ascorbic acid content of the pulp. There is a decrease in ascorbic acid content with increase in voltage gradient. Sugar content present in the fruit can also cause vitamin C breakdown.

\section{Shelf life studies}

\section{Effect of $\mathrm{pH}$ and acidity during storage}

Initially, the $\mathrm{pH}$ of the pulp after ohmic heating at $13.33 \mathrm{~V} / \mathrm{cm}, 20 \mathrm{~V} / \mathrm{cm}$ and $26.66 \mathrm{~V} / \mathrm{cm}$ was observed to be $4.54,4.55$, and 4.62 which decreased during storage leading to increase in acidity as in fig. 3 . The decreasing rate in $\mathrm{pH}$ was less in ohmic heated pulp when compared to the conventional heated pulp. The stability of the $\mathrm{pH}$ depends upon the treatment time and storage condition. [19] reported that there was less percentage of change in $\mathrm{pH}$ when tomato paste was ohmic heated at 6-14 $\mathrm{V} / \mathrm{cm}$. Similar trend for $\mathrm{pH}$ was reported by Hosain et al., (2010) for ohmic heated pomegranate juice.

\section{Effect of Total soluble solids during storage}

The TSS increased marginally with increase in voltage gradient. The TSS of the ohmic heated pulp varied less when compared to the conventionally heated pulp as shown in fig. 4. This is based on the treatment time and storage. The degradation of cellulose, hemicelluloses and pectin from the fruit cell wall leads to the release of soluble components which has an effect on TSS. The solubilization of cell water due to enzyme activity can also be the cause of increase in TSS . The initial TSS of the pulp when ohmic heated at 13.33, 20 and $23.33 \mathrm{~V} / \mathrm{cm}$ was observed to be 25,30 and $32^{\circ}$ brix which has increased to 30,33 and $34^{\circ}$ brix on the $35^{\text {th }}$ day of storage. Similar rate of increase was also found in conventional heated pulp.

\section{Effect of colour during storage}

As in fig. 5 Ohmic heating treatment shows minimal change in colour on prolonged storage. The change in colour can occur due to browning of the juice ${ }^{[19]}$. From the figure, it is shown that the total colour difference increased with increase in sugar concentration and voltage gradient. But the increasing rate is less when compared to the conventional heated pulp. The rate of browning is affected by the storage conditions. The presence of metal ions and oxygen can also lead to browning. Fruit juices can be discoloured due to the activity of oxidative enzymes like POD ${ }^{[17]}$. The active carbonyl groups, which are released on degradation of ascorbic acid, acts as antecedents in enzymatic browning ${ }^{[22]}$.

\section{Effect of ascorbic acid content on storage}

The degradation of ascorbic acid is more in ohmic heated pulp than conventionally heated pulp as shown in fig. 6 . This is because the heating time and retention time of the pulp with increasing sugar concentration are more than that of conventionally heated pulp. Vitamin C is heat labile which causes it to degrade during thermal pasteurization. But during storage the degradation rate of ascorbic acid is less in ohmic heated pulp than in conventionally heated pulp. During 35 day storage, the ascorbic acid values decreased from $6.38 \mathrm{mg} / 100 \mathrm{ml}$ pulp to $5.97 \mathrm{mg} / 100 \mathrm{ml}$ pulp when the pulp with $30 \%$ sugar concentration was ohmically heated at $13.33 \mathrm{~V} / \mathrm{cm}$. whereas in conventionally heated pulp, the ascorbic acid content degraded from 7.7 to $5.9 \mathrm{mg} / 100 \mathrm{ml}$ pulp.

\section{Microbial study}

The microbial growth was observed to be less during storage of ohmic heated pulp when compared to the conventionally heated pulp as shown in table 4 . When pulp with different sugar concentration was ohmic heated at various voltage gradient and stored in refrigeration condition, there was no growth in on the $15^{\text {th }}$ day of storage. Ohmic heated pulp with $10 \%$ and $30 \%$ sugar concentration showed growth of 10 and $6 \mathrm{CFU} / \mathrm{ml}$ which within 
the maximum limit of $10 \mathrm{CFU} / \mathrm{ml}$. This is due to the sugar concentration which enhanced the yeast and mould growth. In conventionally heated pulp with various sugar concentration, the growth was more on the $15^{\text {th }}$ day of about $16 \mathrm{CFU} / \mathrm{ml}$ and $14 \mathrm{CFU} / \mathrm{ml}$ at $10 \%$ and $30 \%$ sugar concentration. Meanwhile, the growth on $50 \%$ sugar was less, this may be due to increase in sugar concentration during which act as a preservative and thereby retards the growth.

\section{CONCLUSION}

The banana pulp with different sucrose concentration was ohmically heated at various voltage gradients. As the sucrose concentration increased, heating time at various voltage gradients also increased with decrease in electrical conductivity. As the voltage gradient increased the $\mathrm{pH}$ and TSS of treated pulp with different sugar concentration were also increased with decrease in colour and acidity. The properties of Ohmic heated pulp were compared with than of conventionally heated pulp. It is been concluded that ohmic heated pulp is better is maintaining shelf life than conventionally heated pulp.

\section{REFERENCES}

1. Ghourchi $\mathrm{H}$ and Barzegar $\mathrm{M}$. Some physicochemical characteristics and degradation kinetic of anthocyanin of reconstituted pomegranate juice during storage. J. Food Eng. 2009; 90, 179-185.

2. Akanbi C. T., Adeyemi R. S., Ojo A. Drying characteristics and sorption isotherm of tomato slices. J Food Eng, 2006; 73: 157-163.

3. Alibas I. O., Akbudak B., Akbudak N. Microwave drying characteristics of spinach. $J$ Food Eng, 2007; 78: 577-583.

4. Contreras C., Martin-Esparza M. E., Chiralt A., Martinez-Navarrete N. Influence of microwave application on convective drying: Effects on drying kinetics, and optical and mechanical properties of apple and strawberry. J Food Eng, 2008; 88: 55-64

5. Duan Z.H., Li-na Jiang, Wang J.I., Yu X.Y., Wang T. Drying and quality characteristics of tilapia fish fillets dried with hot air-microwave heating. Food and Bioproducts processing 2011; 89: 472476.

6. Skudder P.J. Ohmic heating: new alternative for aseptic processing of viscous foods, Food Engineering, 1988; 60, 99-101.

7. Icier F, and Ilicali C. Electrical conductivity of apple and sour cherry juice concentrates during ohmic heating. J. Food Process Eng. 2004; 27 (3), 159- 180.

8. Ye X.F., Ruan R., Chen P., Christopher D. Simulation and veriûcation of Ohmic heating in static heater using MRI temperature mapping. LWT Food Sci. Technol. 2004; 37, 49-58.

9. Sharrock S and Lustry C. Nutritive value of banana. In: Networking Banana and Plantain. INIBAP annual report 1999, p. 28-31. Montpellier, France.

10. Okezie U, Akanbi C.T., Otunola E.T and Adeyemi I.A. Effect of addition of ripe bananas on some physico-chemical properties of maize 'extract'. International Journal of Food Sciences and Nutrition, 2003; 54: 437-445

11. Mohapatra D, Mishra S, Singh C.B. and Jayas D.S. Post-harvest processing of banana: Opportunities and challenges. Food and Bioprocess Technology, 2011; 4: 327-339.

12. Kanazawa K and Sakakibara H. High content of dopamine, a strong antioxidant in Cavendish banana. Journal of Agricultural Food Chemistry, 2000; 48: 844-848.

13. Abid M., Jabbar S., Tao Wu, Hasim M., Bing $\mathrm{Hu}$, ShichengLei, Zhang X and Zeng X. Effect of ultrasound on different quality parameters of apple juice. Ultrasonicssono chemistry, 2013; 20:1182 - 1187.

14. Ranganna 2001: Hand book of Food Analysis.

15. Darvish H., Adel H., Nargesi F and Mohammed H.K. Ohmic Processing: Temperature Dependent Electrical Conductivities for Lemon Juice. Modern Applied Science, 2011; 5(1).

16. Srivastav S and Roy S. Changes in electrical conductivity of liquid foods during ohmic heating. International journal of Agriculture \& Biological Engineering, 2014; 7(5).

17. Icier F and Coskan I. The effects of concentration on electrical conductivity of orange juice concentrates during ohmic heating. European Food Research Technology, 2005; 220, 406-414.

18. Cristina S.C., Moura D.R. and Vitali A.D.A. A Study of Water Activity and Electrical Conductivity in Fruit Juices: Influence of Temperature and Concentration. Brazil Journal Food Technology, 1999; 2: 31-38.

19. Hosain Darvishi, Adel Hosainpour and Farzad Nargesi. Ohmic Heating Behaviour and Electrical Conductivity of Tomato Paste. J. Nutrition and Food Science, 2012; 4-5.

20. Chattopadhyay N., Hore J. K., \& Sen S. K. Extension of storage life of sweet orange (C. 
sinensis Osbeck) cv. Jaffa. Indian Journal of Plant Physiology, 1992; 35, 245 - 251.

21. Echeverria E, Jacoqueline K.B. and Wicker L. Effect of cell wall hysrolysis on Brix in citrus fruits. Proceeding of Florida State Horticulture Society, 1988; 101, 150-154.
22. Leizerson S and Eyal S. Stability And Sensory Shelflife Of Orangejuice Pasteurized By Continuous Ohmic Heating. Agriculture and Food chemistry, 2005; 53(10);4012-4018. 